\title{
Decline in Mycobacterium bovis and Brucella abortus populations during the maturation of experimentally contaminated parmesan-type cheese
}

\section{Decaimento do Mycobacterium bovis e da Brucella abortus durante a cura de queijo tipo parmesão experimentalmente contaminado}

\author{
Karina Ramirez Starikoff ${ }^{1}$; Camila Diniz Fontanesi ${ }^{1}$; Fernanda Moraes Maciel ${ }^{1}$; \\ Cássia Yumi Ikuta ${ }^{1}$; Fernando Ferreira ${ }^{2}$; José Soares Ferreira Neto²; Ricardo \\ Augusto Dias²; Marcos Amaku²; Adriana Cortez ${ }^{3}$; Marcos Bryan Heinemann²; \\ José Henrique Hildebrand Grisi-Filho²; Vítor Salvador Picão Gonçalves ${ }^{4}$; Paulo \\ Henrique Fonseca da Silva ${ }^{5}$; Junio Cesar Jacinto de Paula ${ }^{6}$; Evelise Oliveira Telles ${ }^{2 *}$
}

\begin{abstract}
Brazilian legislation allows the manufacture of raw milk cheese with a maturation exceeding 60 days at room temperature above $5^{\circ} \mathrm{C}$, but there is a lack of solid scientific evidence on the efficacy of this maturation process in inactivating important pathogens that may be present in milk, such as Mycobacterium bovis and Brucella abortus. Thus, the objectives of this study were to produce parmesantype cheese experimentally contaminated with $M$. bovis and B. abortus and evaluate the survival of these pathogens along 2-month maturation. Parmesan-type cheese was manufactured in the laboratory using whole pasteurized milk with or without inoculation with M. bovis (SB1033) or B. abortus (1119-3) and matured at $18^{\circ} \mathrm{C}$ for up to 63 days. M. bovis was inoculated in Stonebrink-Leslie medium supplemented with antibiotics and incubated at $37^{\circ} \mathrm{C}$ for 45 days, and B. abortus was incubated in Farrel medium at $36^{\circ} \mathrm{C}$ for 3 days. The average $\mathrm{D}_{18^{\circ} \mathrm{C}}$ value, weighted by variance, was $37.5 \pm 5.3$ days for M. bovis and 5.9 \pm 0.7 days for $B$. abortus. The average physicochemical parameters in the cheese at the end of the study were as follows: $\mathrm{pH}=4.89$, water activity $=0.976$, and moisture percentage $=43.1 \%$. The $\mathrm{pH}$ might have contributed to the reduction in the population of B. abortus but seems not to have significantly influenced the population of $M$. bovis. We conclude that the duration of the maturation process influences the size of the surviving populations of $M$. bovis and B. abortus, and that the shortening of the maturation duration might not ensure a decline in pathogen levels to safe levels. Thus, complementary studies considering the effect of several other technological aspects on the survival of these pathogens are required, including the effect of the lactic acid bacterial population, salt content, and temperature of maturation.
\end{abstract}

Key words: Brucellosis. Cheese maturation. D-value. Microbial death. Mycobacteria.

1 Discentes, Faculdade de Medicina Veterinária e Zootecnia, Universidade de São Paulo, USP, São Paulo, SP, Brasil. E-mail: kastarikoff@yahoo.com.br; camilafontanesi@uol.com.br; nanda.maciel@yahoo.com.br; cassiayi@yahoo.com.br

2 Profs., Faculdade de Medicina Veterinária e Zootecnia, USP, São Paulo, SP, Brasil. E-mail: fernando@vps.fmvz.usp.br; jsoares@ vps.fmvz.usp.br; dias@vps.fmvz.usp.br; amaku@vps.fmvz.usp.br; marcosbryan@usp.br; grisi@vps.fmvz.usp.br; bufalo@usp. br

3 Prof ${ }^{a}$, Curso de Medicina Veterinária, Universidade de Santo Amaro, São Paulo, SP, Brasil. E-mail: acortez@unisa.br

4 Prof., Faculdade de Agronomia e Medicina Veterinária, Universidade de Brasília, UnB, Brasília, DF, Brasil. E-mail: vitorspg@ unb.br

5 Prof., Instituto de Ciências Biológicas, Universidade Federal de Juiz de Fora, Juiz de Fora, MG, Brasil. E-mail: paulohenrique. ufjf@gmail.com

6 Prof., Instituto de Laticínios Candido Tostes, Empresa de Pesquisa Agropecuária de Minas Gerais, Juiz de Fora, MG, Brasil. E-mail: junio@epamig.br

* Author for correspondence 


\section{Resumo}

A legislação brasileira permite a fabricação queijos de leite cru com maturação superior a 60 dias em temperatura acima de $5^{\circ} \mathrm{C}$, mas falta evidência científica sólida sobre a eficácia do processo de maturação na inativação de importantes patógenos que podem estar presentes no leite, como o Mycobacterium bovis e a Brucella abortus. Assim, os objetivos desse estudo foram produzir o queijo tipo parmesão experimentalmente contaminado com M. bovis e B. abortus e avaliar a sobrevivência desses patógenos ao longo de 2 meses de maturação. Queijo do tipo parmesão foi fabricado em laboratório com leite pasteurizado integral com ou sem inoculo de M. bovis (SB1033) ou B. abortus (1119-3) e maturado a $18^{\circ} \mathrm{C}$ por até 63 dias. M. bovis foi semeado em meio Stonebrink-Leslie, acrescido de antibióticos, e incubado a $37^{\circ} \mathrm{C}$ por 45 dias e a B. abortus foi semeada em meio Farrel a $36^{\circ} \mathrm{C}$ por 3 dias. $\mathrm{O}$ valor $\mathrm{D}_{18^{\circ} \mathrm{C}}$ médio, ponderado pela variância, foi de $37,5 \pm 5,3$ dias para o $M$. bovis e de 5,9 $\pm 0,7$ dias para a $B$. abortus. Os parâmetros físico-químicos médios do queijo no final do estudo foram como se segue: $\mathrm{pH}=$ 4,89 , atividade de água $=0,976$ e umidade percentual $=43,1 \%$. O pH pode ter contribuído para redução da população de $B$. abortus mas parece não ter influenciado significativamente a população de $M$. bovis. Concluiu-se que a duração do processo de maturação influencia o tamanho da população sobrevivente de $M$. bovis e de $B$. abortus e que o encurtamento do período de maturação pode não garantir um declínio desses patógenos para níveis seguros. Assim, estudos complementares que considerem o efeito de vários outros aspectos tecnológicos na sobrevivência desses patógenos são necessários, incluindo o efeito da população de bactérias ácido láticas, teor de sal e temperatura de maturação.

Palavras-chave: Brucelose. Maturação. Micobactéria. Morte microbiana. Valor D.

\section{Introduction}

Mycobacterium bovis and Brucella abortus cause tuberculosis and brucellosis, respectively, in cattle. Milk is one of the main transmission routes of these zoonotic diseases to humans. The extensive and systematic employment of milk pasteurization has significantly reduced the incidence of these diseases in the human population (SINHA, 1994). However, in countries such as Brazil, where these diseases are still currently widespread in herds (BRASIL, 2006a) and the consumption of dairy products prepared with raw milk persists (SOUSA, 2005; ROCHA et al., 2014), it is reasonable to accept the occurrence of human cases by this route of transmission, despite the lack of Brazilian epidemiological data corroborating this hypothesis.

A recent study carried out in 13 Brazilian states, which hold $75 \%$ of the country cattle population, showed the prevalence of tuberculosis infected herds ranging from $0.36 \%$ in the Federal District to $9.0 \%$ in São Paulo (BAHIENSE et al., 2016; BARBIERI et al., 2016; DIAS et al., 2016b; GALVIS et al., 2016; GUEDES et al., 2016; LIMA et al., 2016; NÉSPOLI et al., 2016; QUEIROZ et al., 2016;
RIBEIRO et al., 2016; ROCHA et al., 2016; SILVA et al., 2016a; VELOSO et al., 2016; VENDRAME et al., 2016). In relation to bovine brucellosis, 18 Brazilian states were recently studied, comprising $85 \%$ of the country cattle population, and the prevalence ranged from $0.91 \%$ in Santa Catarina to $30.6 \%$ in Mato Grosso do Sul (ALMEIDA et al., 2016; ALVES et al., 2009; ANZAI et al., 2016; BARDDAL et al., 2016; BAUMGARTEN et al., 2016; BORBA et al., 2013; CLEMENTINO et al., 2016; DIAS et al., 2009; DIAS et al., 2016a; INLAMEA et al., 2016; KLEIN-GUNNEWIEK et al, 2009; LEAL FILHO et al., 2016; OGATA et al., 2009; OLIVEIRA et al., 2016; ROCHA et al., 2009; SILVA et al., 2016b; SILVA et al., 2009).

The informal milk market in 2014 represented $29.6 \%$ of the milk produced in Brazil, i.e., 10,412 billion out of total of 35,174 billion liters of milk (MILKPOINT, 2015). A bulk of this produce goes into the production of derivatives, mainly cheeses, besides a small portion that is retained for personal consumption in the farms. This is attributed to the ease of manufacturing associated with high-value products that are in huge demand. Usually, these 
products are prepared with raw milk and without hygiene and sanitary control measures. This scenario illustrates the potential extent of exposure of the population to products that may be contaminated with $M$. bovis or B. abortus. The exposure is possibly even larger, as Brazilian legislation allows the use of raw milk for the manufacture of certain cheeses, e.g., for cheese with maturation periods exceeding 60 days (BRASIL, 1996) and for the production of so-called artisanal cheeses, which have short maturation or no maturation at all, i.e. in the states of Minas Gerais and Pernambuco (ESTADO DE MINAS GERAIS, 2011; ESTADO DE PERNAMBUCO, 2007).

The survival kinetics of pathogens during the manufacture and maturation of cheese is not well established scientifically, and it is probably influenced by the characteristics of the manufacturing process and the milk matrix, such as $\mathrm{pH}$, water activity (Aw), redox potential (Eh), interaction with accompanying microbiota, presence or absence of a heating step of the milk or curd, and addition of acid.

There have been few studies on the behavior of M. bovis or B. abortus in cheese (FORGRAVE et al., 2014; KARA; AKKAYA, 2015). The occurrence of disease outbreaks caused by M. bovis and Brucella melitensis contamination in cheese made with raw milk in the United States and the United Kingdom (HARRIS et al., 2007; BROUGH et al., 2011) has aroused the interest of the scientific community on the subject. One of the challenges for this type of study is the lack of a specific isolation technique directly from the dairy product for detecting low levels of contamination by these pathogens in the presence of a high load of companion microorganisms, particularly when cells are injured.

The lack of scientific knowledge on the subject highlights the need for pertinent research, especially because there is strong pressure in Brazil to change the federal law to reduce the minimum time of maturation for cheese manufactured from raw milk. The evaluation of microbiological risk associated with length of time of maturation was the technicalscientific parameter set by the government for future decision making on the subject (BRASIL, 2013).

Studies investigating the decline of these pathogens in cheese are complex, expensive, and highly risky for the operator and the environment. Given that many variables can influence the behavior of the microorganisms in cheese, and that the Brazilian legislation has defined the need for studies on the effect of maturation time to ensure the safety of cheese made from raw milk, the objective of this study was to produce parmesantype cheese experimentally infected with $M$. bovis and $B$. abortus and evaluate the survival of these pathogens according to the cheese maturation time.

\section{Material and Methods}

Eight batches of parmesan-type cheese were manufactured with type-A whole pasteurized milk, as described below, at the Laboratory of Food Microbiology, Faculty of Veterinary Medicine and Zootechny, University of São Paulo. Two batches of cheese were produced with milk contaminated with

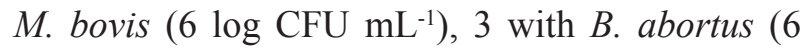
$\log \mathrm{CFU} \mathrm{mL} \mathrm{mL}^{-1}$, and 3 others without inoculum, to determine $\mathrm{pH}$, moisture content ( $\mathrm{M} \%$ ), and $\mathrm{Aw}$ and quantify the indicator microorganisms. The cheeses were maintained at $18^{\circ} \mathrm{C}$ and analyzed at different time points during the maturation.

\section{Inoculum of Mycobacterium bovis}

M. bovis spoligotype SB1033, isolated from cattle slaughtered in the state of São Paulo, was grown at $36^{\circ} \mathrm{C}$ for 15 days in Stonebrink-Leslie medium (CENTRO PANAMERICANO DE ZOONOSIS, 1985). The inoculum was prepared using $0.300 \mathrm{~g}$ of culture, first suspended in $0.5 \mathrm{~mL}$ of $0.85 \%$ saline solution containing $0.05 \%$ Tween 80 , and later made up to $12 \mathrm{~mL}$ with $0.85 \%$ saline solution. Five milliliters of inoculum was used to contaminate $12 \mathrm{~L}$ of milk. 
Inoculum of Brucella abortus

B. abortus strain 1119-3, a variant of biovar 1, provided by the Biological Institute of São Paulo, was cultivated at $36^{\circ} \mathrm{C}$ for 3 days in tryptose agar and then suspended with $0.85 \%$ saline solution until a turbidity equivalent to the 0.5 standard of the McFarland scale was attained. Forty-eight milliliters of inoculum was used to contaminate $12 \mathrm{~L}$ of milk.

Production of cheese experimentally contaminated with B. abortus or M. bovis

Twelve liters of milk inoculated with B. abortus or $M$. bovis was heated in a water bath to $32-$ $35^{\circ} \mathrm{C}$. Previously prepared thermophilic culture blend freeze-dried lactic culture (TCC20; 1 sachet contains $50 \mathrm{IU}$ of lyophilized yeast in $500 \mathrm{~mL}$ of ultra-heat-treated whole milk) was used for cheese production. Twelve milliliters of the culture was used for Direct Vat Set (DVS, Chr Hansen, Brazil), followed by homogenization. After setting this aside for $30 \mathrm{~min}, 6 \mathrm{~mL}$ of calcium chloride, $6 \mathrm{~mL}$ of sodium nitrate, $2.4 \mathrm{~mL}$ of lactic acid, and $3 \mathrm{~mL}$ of liquid coagulant (Três Coroas, Chr Hansen) were added, followed by a further $30 \mathrm{~min}$ of rest for coagulation. The curd was then cut, heated to $50^{\circ} \mathrm{C}$ under homogenization, placed in molds, pressed with a $5-\mathrm{kg}$ weight, maintained at $25^{\circ} \mathrm{C}$ for $24 \mathrm{~h}$, and then salted. The salting process was performed by immersion of the cheese in $2 \mathrm{~L}$ of sterile $20 \%$ saline solution for $2 \mathrm{~h}$, followed by immersion in a bath with natamycin $0.075 \%$ solution $(1.5 \mathrm{~g}$ of Natamax ${ }^{\circledR}$ in $1000 \mathrm{~mL}$ of water). The cheese was transferred to a closed-lid glass container, sealed with Parafilm ${ }^{\circledR}$, and incubated in an oven at $18^{\circ} \mathrm{C}$ for maturation. Daily tumbles were performed for the first 3 days, and subsequently, tumbles were performed on the days of sampling for analysis.
Sample analysis

Milk

The milk used in the manufacture of the contaminated cheese was subjected to assessment for Mycobacterium spp. and Brucella spp. before and after inoculation to quantify the initial load of the bacteria according to the method described below. The milk used in the manufacture of uncontaminated cheese was analyzed for total and fecal coliforms and coagulase-positive Staphylococcus as indicator agents (BRASIL, 2003).

\section{Cheese}

\section{Frequency of analysis}

The enumeration of the indicators in the uninoculated cheeses was performed on days 1,8 , $15,22,29,36,43,50,57$, and 64 . Colonies in the cheese inoculated with $M$. bovis were counted on days $1,7,14,21,28,35,42,49,56$, and 63 , while in cheese inoculated with $B$. abortus, counting was performed twice a week, with successive intervals of 3 and 4 days, until completing 63 days or until 2 consecutive analyses resulted negative results.

\section{Sampling}

A slice of cheese was removed for analysis, and the exposed surface of the cheese was treated with a solution of $0.075 \%$ natamycin, after which the cheese was returned to the aging oven. Our preliminary tests have proven that the natamycin solution employed does not alter the counts of Mycobacterium spp. nor of Brucella spp. (unpublished data).

Physicochemical analyses and enumeration of indicator microorganisms in the uncontaminated samples

The analyses of $\mathrm{M} \%, \mathrm{pH}$, and indicators were performed according to the Brazilian Official Method (BRASIL, 2006b, 2003), while the Aw was measured 
using an Aqualab® series 3TE Decagon (Pullman, Washington, USA) apparatus according to the manufacturer's instructions. The physicochemical analyses were performed in triplicate for each sample, and the average was recorded.

\section{CFU count of $M$. bovis and B. abortus in contaminated samples}

Twenty-five grams of cheese was used for the quantification of the pathogens. For counting $M$. bovis colonies, serial tenfold dilutions were made in $0.1 \%$ peptone water, and $100 \mu \mathrm{L}$ of each dilution in duplicate was seeded in Stonebrink-Leslie medium (CENTRO PANAMERICANO DE ZOONOSIS, 1985 ) containing antibiotics and incubated at $36^{\circ} \mathrm{C}$ for 45 days. To each $120 \mathrm{~mL}$ of Stonebrink-Leslie medium, $3.865 \mathrm{mg}$ of $6,000 \mathrm{IU}$ polymyxin $\mathrm{B}, 0.6$ $\mathrm{mg}$ of amphotericin B, $2.4 \mathrm{mg}$ of nalidixic acid, and $0.6 \mathrm{mg}$ of trimethoprim were added, as adapted from Donaghy et al. (2003).

For the quantification of $B$. abortus, serial tenfold dilution was made in tryptose broth, and 100 $\mu \mathrm{L}$ of each dilution was plated in duplicate in Farrel medium and incubated at $36^{\circ} \mathrm{C}$ for 3 days.

Colonies were counted in the dilutions that showed between 10 and 150 colonies, and the results were expressed in log CFU per milliliter (milk) or gram (cheese).

\section{Calculation of the D-value}

The D-value is a unit internationally recognized by microbiologists, and in this case, it represents the time required for $1 \log$ decrease in the count of the microbe for a given condition of cheese ripening (FORGRAVE, 2014). A linear regression equation was used to fit the number of surviving bacteria in the cheese as a function of the time of maturation, and the regression line was used to calculate the $\mathrm{D}_{18^{\circ} \mathrm{C}}$ value of each microorganism for each sample of cheese. The average value of $\mathrm{D}_{18^{\circ} \mathrm{C}}$ was expressed for each microorganism, weighted by the variance.
Biosecurity measures in the manufacture and analysis of contaminated cheese

During the manufacture of cheese, only authorized people remained in the laboratory, and no personnel entered or exited the facility until the manufacturing process was over. Individual protection equipment (IPE) used were long-sleeved cotton laboratory coats, long cotton pants, socks, and rubber boots barreled into the pants, all of which were reusable. Over these items, a disposable long-sleeved laboratory coat with a closed back and another tied around the waist to protect the legs were worn. In addition, a disposable bathing cap, safety glasses (Rimpac, model A.C. 8126), disposable protection mask (Descarpack, N 95), and 2 disposable rubber gloves on each hand were used. The external pair of gloves was changed frequently to reduce the chance of spread of contamination to other utensils or the environment. The utensils used in manufacturing were immersed in a disinfectant solution immediately after use. For the aluminum or stainless steel materials, formol solution (Lysoform ${ }^{\circledR}$ 1:10 v/v) was used, and for plastic or glass materials, bleach was used (Candida ${ }^{\circledR}$ 1:2 $\mathrm{v} / \mathrm{v})$.

After the manufacture, the aluminum containers with the waste material, such as water in the water bath, whey, and cheese leftovers, were packaged in autoclavable bags. Lysoform ${ }^{\circledR}$ was added in sufficient quantity for a final concentration of $1: 2 \mathrm{v} / \mathrm{v}$ or $1: 3 \mathrm{v} / \mathrm{v}$, and the bags were sealed. The floor of the laboratory was wiped a disposable cloth soaked in Lysoform ${ }^{\circledR}$. This cloth and the IPE were packaged in autoclavable bags, and the disposable materials were separated from the reusable materials. Formalin tablets (Ricie $\AA$ ) were added to the bags and sealed. The laboratory was fumigated using $20 \mathrm{~mL}$ of formaldehyde added to $10 \mathrm{~g}$ of potassium permanganate per $\mathrm{m}^{3}$ of space (SOBESTIANSKY et al., 1998) and kept closed for $24 \mathrm{~h}$. All the material remained in the laboratory in this period and was later autoclaved at $121^{\circ} \mathrm{C} / 15 \mathrm{~min}$ (except the boots and glasses, which were washed 
with $1: 10 \mathrm{v} / \mathrm{v}$ Lysoform $\left.{ }^{\circledR}\right)$. The entire manipulation of cheese and samples was performed in a laminar flow fume hood (VECO, mod. VLFS-18FL Series 7090; Campinas, São Paulo, Brazil).

\section{Results and Discussion}

No detectable levels of the indicator microorganisms of $M$. bovis or B. abortus (total and fecal coliforms and coagulase-positive Staphylococcus) were detected in the uninoculated milk, which is as expected for pasteurized milk (BRASIL, 2011). Similarly, there was no growth of the indicator microorganisms in cheese produced with uninoculated milk until the end of the study. This can be partly explained by the absence of detectable levels of these agents in milk and partly by the aseptic conditions during the cheese production in the laboratory. This reduces the chance of pathogen decline in the study from being directly influenced by these agents or their metabolites. Some of these contaminants are prolific producers of acids and, according to Macuamule et al. (2016), the quantity and type of acid produced can affect the kinetics of M. bovis death.

In inoculated milk, the initial average loads of $M$. bovis and B. abortus were, respectively, $6.1 \mathrm{log}$ $\mathrm{CFU} \mathrm{mL} \mathrm{mL}^{-1}$ and $5.8 \log \mathrm{CFU} \mathrm{mL} \mathrm{m}^{-1}$, while on day 1 of the cheese processing, the average loads were $5.5 \log \mathrm{CFU} \mathrm{g} \mathrm{g}^{-1}$ and $5.4 \log \mathrm{CFU} \mathrm{g} \mathrm{g}^{-1}$, respectively (Table 1). Note that the processing of milk into cheese reduced the population of the inoculated bacteria, which is probably associated with the loss of microorganisms in the serum fraction, in addition to a relative increase in remnant population, due to the concentration of solids. This phenomenon was also observed in the experimental production of cheddar and Caerphilly cheese inoculated with M. bovis (FORGRAVE et al., 2014), as well as in cheddar cheese inoculated with M. paratuberculosis (DONAGHY et al., 2004).

Table 1. Counts of Mycobacterium bovis SB1033 and Brucella abortus 1119-3 in milk and during the maturation $\left(18^{\circ} \mathrm{C}\right)$ of parmesan-type cheese.

\begin{tabular}{|c|c|c|c|c|c|c|c|c|c|c|c|c|}
\hline \multirow[b]{2}{*}{ agent } & \multirow{2}{*}{$\begin{array}{l}\text { cheese } \\
\text { sample }\end{array}$} & \multicolumn{11}{|c|}{ agent count } \\
\hline & & milk (log & & & & & heese (lo & CFU g & & & & \\
\hline \multirow{6}{*}{ 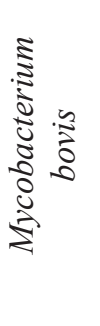 } & & & day 1 & day 7 & day 14 & day 21 & day 28 & day 35 & day 42 & day 49 & day 56 & day 63 \\
\hline & 1 & 6.0 & $*$ & 5.3 & 5.0 & 4.9 & 4.6 & 5.0 & 3.9 & 4.3 & 4.1 & 4.3 \\
\hline & 2 & 6.1 & 5.5 & 5.7 & 5.0 & 4.5 & 4.3 & 4.3 & 4.1 & 4.3 & 3.7 & 3.9 \\
\hline & average & 6.1 & 5.5 & 5.5 & 5.0 & 4.7 & 4.5 & 4.7 & 4.0 & 4.3 & 3.9 & 4.1 \\
\hline & $\begin{array}{l}\text { standard } \\
\text { deviation }\end{array}$ & 0.07 & & 0.28 & 0.00 & 0.28 & 0.21 & 0.49 & 0.14 & 0.00 & 0.28 & 0.28 \\
\hline & & & day 1 & day 4 & day 8 & day 11 & day 15 & day 18 & day 22 & day 25 & day 29 & day 32 \\
\hline \multirow{5}{*}{ 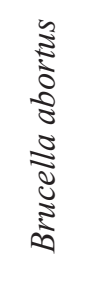 } & 1 & 6.2 & 5.7 & 5.4 & 3.9 & 4.3 & 4.8 & 4.1 & 4.0 & 2.2 & 0.0 & 0.0 \\
\hline & 2 & 5.8 & 5.8 & 6.0 & 4.0 & 4.8 & 2.5 & 2.5 & 0.0 & 0.0 & $* * *$ & $* * *$ \\
\hline & 3 & 5.5 & 4.8 & 4.6 & 3.9 & 3.0 & $0.0^{* * *}$ & 1.7 & 0.0 & 1.7 & 0.0 & 0.0 \\
\hline & average & 5.8 & 5.4 & 5.3 & 3.9 & 4.0 & 2.4 & 2.8 & 1.3 & 1.3 & 0.0 & 0.0 \\
\hline & $\begin{array}{l}\text { standard } \\
\text { deviation }\end{array}$ & 0.4 & 0.6 & 0.7 & 0.1 & 0.9 & 2.4 & 1.2 & 2.3 & 1.2 & 0.0 & 0.0 \\
\hline
\end{tabular}

* Lost dat

** No growth at the lowest dilution $\left(<50 \mathrm{CFU} \mathrm{g}^{-1}\right)$

*** Sample not analyzed because the 2 preceding ones were negative. 
The affinity of mycobacteria for fat (MCFADDEN et al., 1992) might result in a smaller reduction in M. bovis numbers during the processing of milk to cheese compared to $B$. abortus, but the difference between these bacteria was minor. This can be attributed to the tendency for lump formation by M. bovis (MCFADDEN et al., 1992), which could result in a lower number of $\mathrm{CFU} \mathrm{g}^{-1}$.

The maturation time of the cheese at $18^{\circ} \mathrm{C}$ negatively affected the survival of both the pathogens, but the decay rate was more accentuated for B. abortus than for M. bovis. While the population of $B$. abortus was reduced to undetectable levels by our technique $\left(<50 \mathrm{CFU} \mathrm{g}^{-1}\right.$ or $\left.<1.7 \log \mathrm{CFU} \mathrm{g} \mathrm{g}^{-1}\right)$ in a maximum of 29 days of maturation, M. bovis remained in quantifiable levels until the end of the study, with an average reduction of $1.4 \log$ CFU g ${ }^{-1}$ (Table 1).

The decay curves of $M$. bovis according to the time of maturation are represented in Figure 1 and those of B. abortus in Figure 2. The average $\mathrm{D}_{18^{\circ} \mathrm{C}}$ value, weighted by the uncertainties, was $37.5 \pm$ 5.3 days for $M$. bovis, indicating that, with $95 \%$ confidence, the $\mathrm{D}_{18^{\circ} \mathrm{C}}$ value lies between 27.1 and 47.9 days. For B. abortus, the average value was $5.9 \pm 0.7$ days, i.e., the $\mathrm{D}_{18^{\circ} \mathrm{C}}$ value of this agent lies between 4.6 and 7.1 days with $95 \%$ confidence.

Studies on the persistence of $M$. bovis and $B$. abortus in cheeses have been limited, but quantitative assessments of survival of these agents after cheese maturation are even scarcer. In the only study found, which used a methodology similar to the one used in this study, the average $\mathrm{D}_{12^{\circ} \mathrm{C}}$ values obtained for M. bovis were 50.75 and 57.59 days, respectively, in cheddar and Caerphilly cheese produced with milk containing a high initial load (5-6 $\log$ CFU mL $\mathrm{mL}^{-1}$ ), and 30.49 days and 21.48 days, respectively, when produced with a low initial load (2-3 log CFU mL $\mathrm{mL}^{-1}$ ) (FORGRAVE et al., 2014). In another study, viable $M$. bovis was detected after 3-4 months of maturation of artificially contaminated

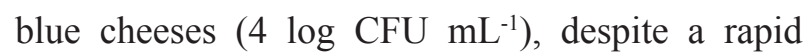
reduction in the population in the first 14 days after the manufacture (LAFONT; LAFONT, 1981). Certain studies have determined D-values for M. paratuberculosis in a variety of cheeses. The D-value curve of temperature $\left(12{ }^{\circ} \mathrm{C}-22^{\circ} \mathrm{C}-12^{\circ} \mathrm{C}\right)$ was 27.8 days in semi-hard Swiss cheese (Tilsiter), while in medium-hard Swiss cheese (Emmental), the $\mathrm{D}_{15^{\circ} \mathrm{C}}$ was 45.5 days (SPAHR; SCHAFROTH, 2001). In white soft cheese (Queso Fresco), the $\mathrm{D}_{4^{\circ} \mathrm{C}}$ value was 59.9 days (SUNG; COLLINS, 2000). In cheddar-type cheese, the $\mathrm{D}_{10^{\circ} \mathrm{C}}$ values were 90,96 , and 107 days, respectively, for a reference strain (NCTC) and two isolates from milk, reinforcing the theory that the strains cultivated in the laboratory for long periods are less resistant (DONAGHY et al., 2004).

No data for D-values are available for B. abortus in cheeses, but studies have reported the survival of this bacterium in cheese. Gilman et al. (1946) observed B. abortus in samples of cheddar cheese with 6 months of storage. Plommet et al. (1988) assessed B. abortus in camembert cheese manufactured from cows' milk infected experimentally and reported that the initial load in the cheese (3-4 log CFU g ${ }^{-1}$ ) was reduced to undetectable levels after 18 days at $12^{\circ} \mathrm{C}$. Méndez-González et al. (2011) reported the influence of maturation temperature of cheese on the survival of $B$. melitensis, which was recovered up to 50 days after maturation at $4^{\circ} \mathrm{C}$ and up to 20 days after maturation at $24^{\circ} \mathrm{C}$. Kara and Akkaya (2015) studied the survival of Brucella spp. during the maturation of Afyon Tulum cheese and reported that the survival of $B$. abortus was influenced by the initial load: it was detected up to the $15^{\text {th }}$ day of maturation when the inoculum was $4 \log \mathrm{CFU} \mathrm{g}^{-1}$ and until the $45^{\text {th }}$ day when the inoculum was $6 \log \mathrm{CFU}$ $\mathrm{g}^{-1}$; however, B. melitensis was inhibited on the $30^{\text {th }}$ day of maturation with either of the initial loads. The variability in the survival of the pathogens during the maturation of various cheeses found by different studies can be explained by differences in the manufacturing technology, maturation temperature, physicochemical characteristics of the milk matrix, companion microbiota, and other aspects related to the methodology used in the study. 
Figure 1. Decay curve of Mycobacterium bovis spoligotype SB 1033 in parmesan-type cheese during maturation at $18^{\circ} \mathrm{C}$.

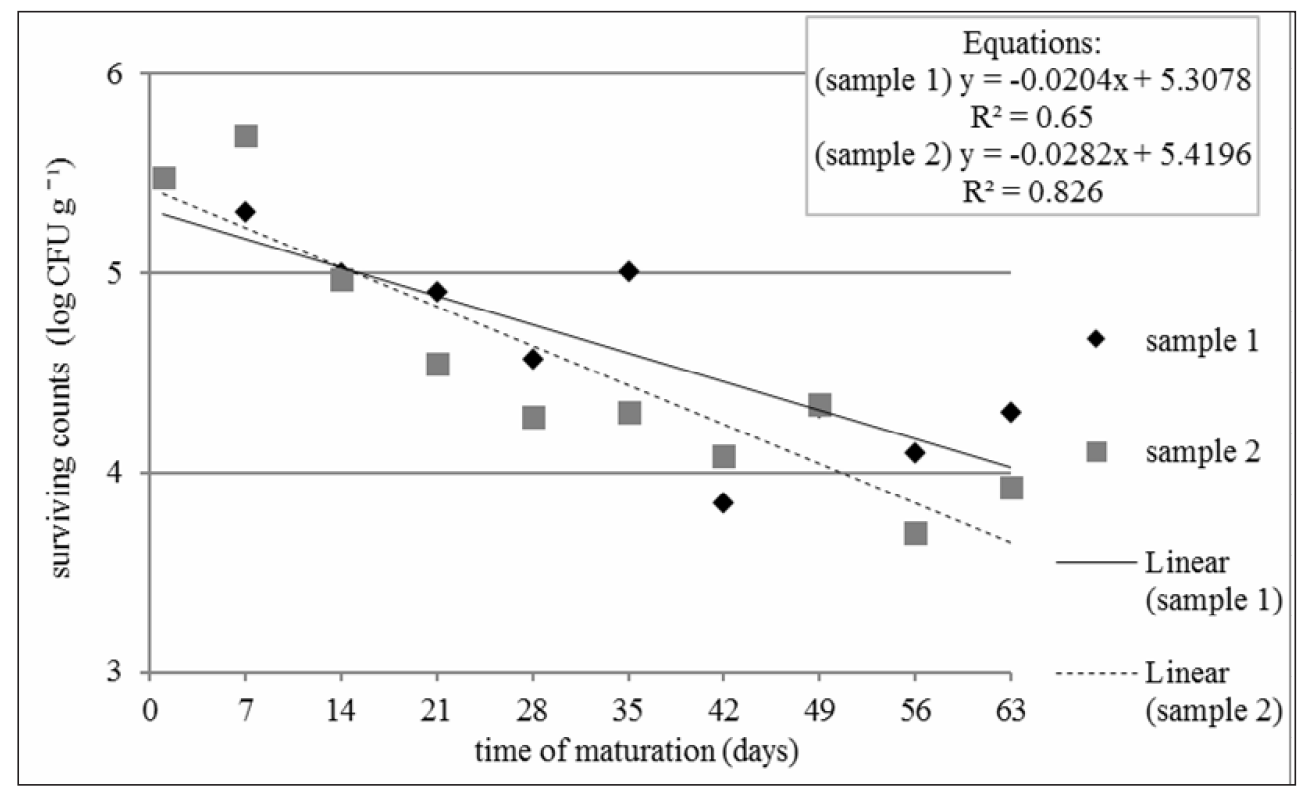

Obs. day 1 of cut 1: lost data.

Figure 2. Decay curve of Brucella abortus 1119-3 in parmesan-type cheese during maturation at $18^{\circ} \mathrm{C}$.

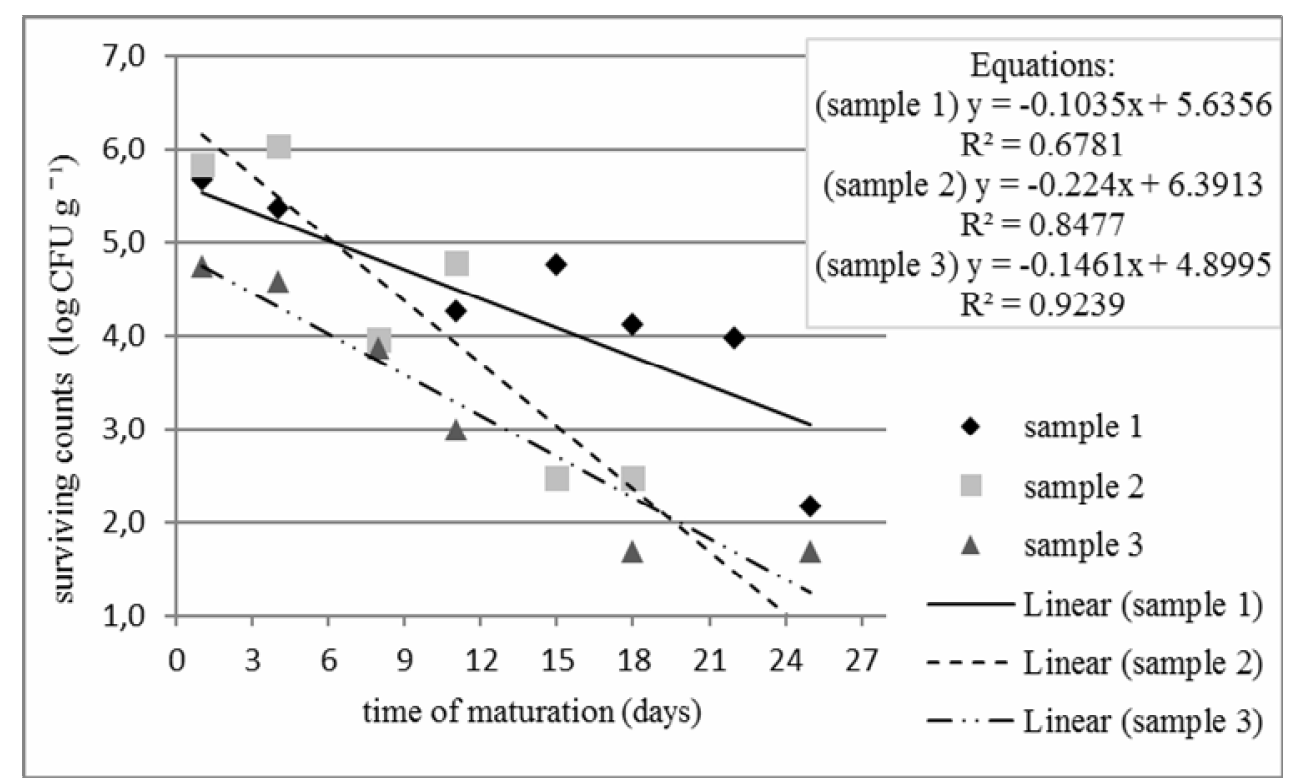

Obs. We considered only the time points at which it was possible to quantify Brucella: until day 25 in cuts 1 and 3 and until day 18 in cut 2 .

Regarding the effect of maturation at $18^{\circ} \mathrm{C}$ on the physicochemical parameters studied, the $\mathrm{pH}$ of the cheese decreased from 5.57 to 4.89 , while the Aw decreased from 0.980 to 0.976 and the $\mathrm{M} \%$ from 44.7 to $43.1 \%$ (Table 2). $\mathrm{M} \%$ is the legal parameter used to establish the microbiological criteria in cheeses. The M\% obtained in this study $(<35.9 \%)$ did not meet the legal standard for parmesan typecheese (BRASIL, 1996), which was expected since the maturation time in this study was lower than that required for the commercial product (180 days) (BRASIL, 1997). 
Table 2. Results of the physicochemical analysis of parmesan-type cheese matured at $18^{\circ} \mathrm{C}$.

\begin{tabular}{cccccccccccc}
\hline \multirow{2}{*}{ parameter } & \multirow{2}{*}{} & sample & \multicolumn{10}{c}{ sampling } \\
\cline { 3 - 12 } & & day 1 & day 7 & day 14 & day 21 & day 28 & day 35 & day 42 & day 49 & day 56 & day 63 \\
\hline \multirow{4}{*}{ Aw } & 1 & 0.983 & 0.997 & 0.977 & 0.981 & 0.982 & 0.981 & 0.978 & 0.977 & 0.978 & 0.98 \\
& 2 & 0.989 & 0.98 & 0.982 & 0.976 & 0.983 & 0.978 & 0.973 & 0.978 & 0.977 & 0.964 \\
& 3 & 0.968 & 0.98 & 0.976 & 0.978 & 0.977 & 0.975 & 0.978 & 0.971 & 0.97 & 0.983 \\
& average & 0.980 & 0.986 & 0.978 & 0.978 & 0.981 & 0.978 & 0.976 & 0.975 & 0.975 & 0.976 \\
& 1 & 47.3 & $*$ & 44.0 & 40.7 & 43.3 & 44.7 & 42.7 & 44.0 & 44.7 & 44.0 \\
\multirow{2}{*}{ M\% } & 2 & $*$ & 42.0 & 42.0 & 45.3 & 44.0 & 43.3 & 44.7 & 43.3 & 42.7 & 41.3 \\
& 3 & 42.0 & 34.7 & 42.0 & 44.0 & 42.7 & 41.3 & 40.0 & 42.7 & 42.7 & 44.0 \\
& average & 44.7 & 38.4 & 42.7 & 43.3 & 43.3 & 43.1 & 42.5 & 43.3 & 43.4 & 43.1 \\
& 1 & 5.51 & 5.24 & 5.21 & 5.28 & 5.14 & 4.64 & 4.58 & 4.61 & 4.59 & 4.79 \\
\multirow{4}{*}{$\mathrm{pH}$} & 2 & 5.54 & 5.3 & 5.34 & 5.19 & 4.89 & 4.89 & 4.73 & 4.61 & 4.8 & 4.82 \\
& 3 & 5.66 & 5.24 & 5.27 & 4.86 & 4.91 & 4.92 & 4.93 & 4.72 & 4.97 & 5.07 \\
& average & 5.57 & 5.26 & 5.27 & 5.11 & 4.98 & 4.82 & 4.75 & 4.65 & 4.79 & 4.89 \\
\hline
\end{tabular}

* Lost data.

Brazilian legislation does not establish acceptance criteria for the other physicochemical parameters studied, although they play a relevant role in the control of microbial development in food. Acidity is an important factor for ensuring the development of lactic microbiota and for maintaining the different enzymatic reactions during cheese maturation (SALÄUN et al., 2005), while Aw is widely regarded as a major factor determining microbial growth (JAY, 2000).

Although the borderline values specific to $M$. bovis are not defined, this bacterium is renowned for its high resistance to acidic and alkaline environments (ROWE; DONAGHY, 2008). However, the growth of $B$. abortus is limited by $\mathrm{pH}$ values below 4.5 5.1 and above 8.2-8.8, temperatures below $6^{\circ} \mathrm{C}$ and above $42^{\circ} \mathrm{C}$, and salt concentrations above $4 \%$ (ICMSF, 1996). The $\mathrm{pH}$ of the cheese obtained in this study was close to the minimum limit allocated to the growth of B. abortus; therefore, it is possible that this factor had an important effect on the decrease in this population, as has been observed by Falenski (2011). The salt content in the curd was not studied here, and therefore, we could not evaluate the participation of this factor in the decay of B. abortus.

Méndez-González et al. (2011) evaluated the survival of $B$. melitensis in goat cheese subjected to two maturation temperatures for demonstrating the interrelationship of technological parameters with the physicochemical characteristics of the final product and the survival of pathogens. Their results showed that when the maturation was performed at $4^{\circ} \mathrm{C}$, the $\mathrm{pH}$ of the cheese was 5.0 and the bacteria were detected up to the $50^{\text {th }}$ day, and when performed at $24^{\circ} \mathrm{C}$, the $\mathrm{pH}$ of the cheese was 4.0 and the bacteria were detected up to the $20^{\text {th }}$ day.

It is important to highlight that the D-values of strains circulating in the country may be greater than those obtained in this study because circulating strains tend to be more resistant than those maintained for long periods in the laboratory. However, in actual conditions, it is likely that the lactic acid bacteria (LAB) in raw milk and "starter" cultures can interfere negatively with the survival of these pathogens. Macuamule et al. (2016) studied the effect of milk fermentation on the inactivation of $M$. bovis BCG and observed that the phenomenon was influenced by both the quantity and variability of the LAB population and metabolites produced, such as acids and bacteriocins.

Assuming the worst case scenario, in which milk presents the maximum natural contamination, i.e., $4 \log$ CFU $\mathrm{mL}^{-1}$ M. bovis (BALL, 1943) and B. abortus (CAPPARELLI et al., 2009), and that 
cheese maturation results in a lower rate of decline envisaged by the study (which is the upper value of the confidence interval), we simulated microbial load survival in the product ready for consumption, taking 4 periods of maturation: 10, 20, 30, and 60 days (Table 3). The significance of these results is difficult to interpret, given that the dose-response in humans by oral route is not well established for any of these agents, but it is suggested that the infectious doses for $M$. bovis is on the order of ten to millions of cells and fewer than 500 organisms for Brucella spp. (FDA, 2012). In the particular case, the consumption of $10 \mathrm{~g}$ of cheese could largely surpass the more conservative infectious dose suggested for
$M$. bovis, at any stage of simulated maturation; the same could be noted for Brucella until the $20^{\text {th }}$ day of maturation.

We demonstrated the production of cheese experimentally infected with strains of $B$. abortus and $M$. bovis. We also showed that the extension of the maturation negatively influenced the size of the surviving population, and that the shortening of the maturation time cannot ensure the reduction of these pathogens to safe levels. However, due to the uncertainties and variability related to the phenomena measured in this study, other studies are necessary to evaluate the degree of safety obtained by the maturation of cheese prepared from raw milk.

Table 3 Simulation of surviving levels of $M$. bovis or B. abortus in parmesan-type cheese subjected to maturation at $18^{\circ} \mathrm{C}$ for different periods in the worst case scenario.

\begin{tabular}{|c|c|c|c|c|c|c|c|}
\hline \multirow{2}{*}{ Agent } & \multirow{2}{*}{$\begin{array}{l}\text { Initial load in } \\
\text { the milk (log } \\
\left.\text { CFU mL }{ }^{-1}\right)^{*}\end{array}$} & \multirow{2}{*}{$\begin{array}{l}\text { Initial load in } \\
\text { the cheese }(\log \\
\left.\text { CFU g }{ }^{-1}\right)^{* *}\end{array}$} & \multirow{2}{*}{$\begin{array}{c}\mathrm{D} 18^{\circ} \mathrm{C} \\
\text { value } \\
\text { (days) }^{* * *}\end{array}$} & \multicolumn{4}{|c|}{$\begin{array}{l}\left.\text { Level of surviving counts (log CFU } g^{-1}\right) \text { after a } \\
\text { maturation period of: }\end{array}$} \\
\hline & & & & 10 days & 20 days & 30 days & 60 days \\
\hline $\begin{array}{l}\text { M. bovis } \\
\text { (SB1033) }\end{array}$ & 4 & 3.4 & 48 & 3.2 & 3.0 & 2.8 & 2.2 \\
\hline $\begin{array}{l}\text { B. abortus } \\
(1119-3)\end{array}$ & 4 & 3.6 & 7 & 2.2 & 0.7 & -0.7 & -5.0 \\
\hline
\end{tabular}

* Maximum natural contamination of milk reported in the literature, according to Ball (1943) (M. bovis) and Capparelli et al. (2009) (B. abortus).

** Estimated population in the cheese considering the effect of the processing of the milk into cheese observed in this study: reduction of $0.6 \log \mathrm{CFU} \mathrm{g}^{-1}$ for M. bovis and $0.4 \log \mathrm{CFU} \mathrm{g}^{-1}$ for B. abortus.

$* * *$ Time required to reduce the agent by $1 \log$ (upper value of the $95 \%$ confidence interval), as obtained in the present study.

\section{Acknowledgements}

The authors acknowledge the financial support from CAPES and CNPq.

\section{References}

ALMEIDA, E. C.; FREITAS, A. A.; PONTUAL, K. A. Q.; SOUZA, M. M. A.; AMAKU, M.; DIAS, R. A.; FERREIRA, F.; TELLES, E. O.; HEINEMANN, M. B.; GONÇALVES, V. S. P.; EVÊNCIO NETO, J.; MARVULO, M. F. V.; GRISI-FILHO, J. H. H.; FERREIRA NETO, J. S.; SILVA, J. C. R. Prevalence and associated risk factors for bovine brucellosis in the state of Pernambuco, Brazil. Semina: Ciências Agrárias, Londrina, v. 37, n. 5, p. 3413-3424, 2016. Suplemento 2.
ALVES, A. J. S.; GONÇALVES, V. P. S.; FIGUEIREDO, V. C. F.; LOBO, J. R.; BAHIENSE, L.; AMAKU, M.; FERNANDO, F.; FERREIRA NETO, J. S.; DIAS, R. A. Situação epidemiológica da brucelose bovina no Estado da Bahia. Arquivo Brasileiro de Medicina Veterinária e Zootecnia, Belo Horizonte, v. 61, p. 6-13, 2009. Suplemento 1.

ANZAI, E. K.; COSTA, D.; SAID, A. L. P. R.; GRISI-FILHO, J. H. H.; AMAKU, M.; DIAS, R. A.; FERREIRA, F.; GALVIS, J. O. A.; GONÇALVES, V. S. P.; HEINEMANN, M. B.; TELLES, E. O.; FERREIRA NETO, J. S. An update on the epidemiological situation of bovine brucellosis in the state of Espírito Santo, Brazil. Semina: Ciências Agrárias, Londrina, v. 37, n. 5, p. 3437-3448, 2016. Suplemento 2. 
BAHIENSE, L.; ÁVILA, L. N. de; BAVIA, M. E.; AMAKU, M.; DIAS, R. A.; GRISI-FILHO, J. H. H.; FERREIRA, F.; TELLES, E. O.; GONÇALVES, V. S. P.; HEINEMANN, M. B.; FERREIRA NETO, J. S. Prevalence and risk factors for bovine tuberculosis in the State of Bahia, Brazil. Semina: Ciências Agrárias, Londrina, v. 37, n. 5, p. 3549-3560, 2016. Suplemento 2.

BALL, C. O. Short-time pasteurization of milk. Industrial Engineering Chemistry, v. 35, p. 71-84, 1943.

BARBIERI, J. M.; OLIVEIRA, L. F.; DORNELES, E. M. S.; MOTA, A. L. A. A.; GONÇALVES, V. S. P.; MALUF, P. P.; FERREIRA NETO, J. S.; FERREIRA, F.; DIAS, R. A.; TELLES, E. O.; GRISI-FILHO, J. H. H.; HEINEMANN, M. B.; AMAKU, M.; LAGE, A. P. Epidemiological status of bovine tuberculosis in the state of Minas Gerais, Brazil, 2013. Semina: Ciências Agrárias, Londrina, v. 37, n. 5, p. 3531-3548, 2016. Suplemento 2.

BARDDAL, J. E. I.; SANTOS, J. C. Q.; LOPES, I. F.; FERREIRA NETO, J. S.; FERREIRA, F.; AMAKU, M.; DIAS, R. A.; TELLES, E. O.; GRISI-FILHO, J. H. H.; HEINEMANN, M. B.; GONÇALVES, V. S. P.; AGUIAR, D. M. Effect of vaccination in lowering the prevalence of bovine brucellosis in the state of Mato Grosso, Brazil. Semina: Ciências Agrárias, Londrina, v. 37, n. 5, p. 3479-3492, 2016. Suplemento 2.

BAUMGARTEN, K. D.; VELOSO, F. P.; GRISI-FILHO, J. H. H.; FERREIRA, F.; AMAKU, M.; DIAS, R. A.; TELLES, E. O.; HEINEMANN, M. B.; GONÇALVES, V. S. FERREIRA NETO, J. S. Prevalence and risk factors for bovine brucellosis in the State of Santa Catarina, Brazil. Semina: Ciências Agrárias, Londrina, v. 37, n. 5, p. 3413-3424, 2016. Suplemento 2.

BORBA, M. R.; STEVENSON, M. A.; GONÇALVES, V. S. P.; FERREIRA NETO, J. S.; FERREIRA, F.; AMAKU, M.; TELLES, E. O.; SANTANA, S. S.; FERREIRA, J. C. A.; LOBO, J. R.; FIGUEIREDO, V. C. F.; DIAS, R. A. Prevalence and risk-mapping of bovine brucellosis in Maranhão state, Brazil. Preventive Veterinary Medicine, Colorado, v. 110, n. 2, p. 169-176, 2013.

BRASIL. Ministério da Agricultura Pecuária e Abastecimento. Manual Técnico do Programa Nacional de Controle e Erradicação da Brucelose e Tuberculose (PNCEBT). Organizadores: FIGUEIREDO, V. C. F.; LÔBO. J. R.; GONÇALVES, V. S. P. Brasília: MAPA/ SDA/DSA, 2006a. 188 p. Disponível em: http:// www.agricultura.gov.br/arq_editor/file/Aniamal/ programa\%20nacional \%20sanidade \%20brucelose / Manual\%20do\%20PNCEBT\%20-\%20Original.pdf $>$. Acesso em: 14 dez. 2015.
BRASIL. Ministério da Agricultura, Pecuária e Abastecimento. Instrução Normativa n. 62, de 29 de dezembro de 2011. Regulamento técnico de produção, identidade e qualidade do leite tipo a, regulamento técnico de identidade e qualidade do leite cru refrigerado, regulamento técnico de identidade e qualidade do leite pasteurizado e regulamento técnico da coleta do leite cru refrigerado e seu transporte a granel. 2011. Brasília: MAPA. Disponível em: http://sistemasweb.agricultura. gov.br/sislegis/action/detalhaAto.do?method =detalharA tosArvore\&tipo $=I N M \&$ numeroAto $=00000062 \&$ seqAto $=000 \&$ valorAno $=2011 \&$ orgao $=$ MAPA $\& \operatorname{codTipo}=\&$ des $I$ tem $=\&$ desItemFim $=\&$ nomeTitulo $=$ codigos. Acesso em: 4 out. 2016.

Portaria 146 de 7 de março de 1996. Regulamento técnico de identidade e qualidade de queijos. Regulamento técnico geral para a fixação dos requisitos microbiológicos de queijo. Brasília: MAPA, 1996. Disponível em: <http://extranet.agricultura. gov.br/sislegis-consulta/consultarLegislacao.do? operacao=visualizar\&id $=1218>$. Acesso em: $14 \mathrm{dez}$. 2015.

Instrução Normativa n.62, de 26 ago.

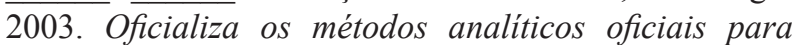
análises microbiológicas para controle de produtos de origem animal e água. Brasília: MAPA, 2003. Disponível em: http://extranet.agricultura.gov.br/sislegis-consulta/ consultarLegislacao. do operacao $=$ visualizar $\& i d=2851$. Acesso em: 14 dez. 2015.

Secretaria de Defesa Agropecuária. Instrução Normativa n.68, de $12 \mathrm{dez}$. 2006. Oficializa os Métodos Analíticos Oficiais Físico-Químicos, para Controle de Leite e Produtos Lácteos, em conformidade com o anexo desta Instrução Normativa, determinando que sejam utilizados nos Laboratórios Nacionais Agropecuários. Brasília, 2006b. Disponível em: $<$ http://extranet.agricultura.gov.br/sislegis-consulta/ consultarLegislacao.do? operacao $=$ visualizar \& id=17472 $>$. Acesso em: 14 dez. 2015.

Instrução Normativa n. 30 de 07 de $\overline{\text { agosto }}$ de 2013. Dispõe sobre o período de maturação dos queijos artesanais tradicionalmente elaborados a partir de leite cru. Brasília: MAPA, 2013. Disponível em: $<$ http://sistemasweb.agricultura.gov.br/sislegis/action/ detalhaAto.do?method=consultarLegislacao Federal $>$. Acesso em: 14 dez. 2015.

Regulamento Técnico de Identidade e Qualidade de Queijo Parmesão. Portaria 353, de 4 de setembro de 1997. Aprova o regulamento técnico para fixação de identidade e qualidade de queijo Parmesão, Parmesano, Reggiano, Reggianito e Sbrinz. Brasília: MAPA, 1997. Disponível em: <http:// extranet. 
agricultura.gov.br/sislegis-consulta/consultarLegislacao. do? operacao=visualizar\&id $=1223>$. Acesso em: $14 \mathrm{dez}$. 2015.

BROUGH, H. A.; SOLOMON, A. W.; WALL, R. A.; ISAZA, F.; PASVOL, G. Brucellosis acquired by eating imported cheese. Journal of Paediatrics and Child Health, Oxford, v. 47, n. 11, p. 840-841, 2011.

CAPPARELLI, R.; PARLATO, M.; IANNACCONE, M.; ROPERTO, S.; MARABELLI, R.; ROPERTO, F.; IANNELLI, D. Heterogeneous shedding of Brucella abortus in milk and its effect on the control of animal brucellosis. Journal of Applied Microbiology, v. 106, n. 6, p. 2041-2047, 2009.

CENTRO PANAMERICANO DE ZOONOSIS CEPANZO. Manual de normas y procedimentos técnicos para la bacteriología de la tuberculosis. Buenos Aires: OPAS/OMS, 1985. $30 \mathrm{p}$.

CLEMENTINO, I. J.; DIAS, R. A.; AMAKU, M.; FERREIRA, F.; TELLES, E. O.; HEINEMANN, M. B.; GONÇALVES, V. S. P.; GRISI-FILHO, J. H. H.; FERREIRA NETO, J. S.; ALVES, C. J.; SANTOS, C. S. A. B.; AZEVEDO, S. S. Epidemiological situation of bovine brucellosis in the state of Paraiba, Brazil. Semina: Ciências Agrárias, Londrina, v. 37, n. 5, p. 3403-3412, 2016. Suplemento 2.

DIAS, J. A.; MÜLLER, E. E.; DIAS, R. A.; FREITAS, J. C.; AMAKU, M.; FERREIRA, F.; SILVA, M. C. P.; LOBO, J. R.; FIGUEIREDO, V. C. F.; GONÇALVES, V. S. P.; FERREIRA NETO, J. S. Situação epidemiológica da brucelose bovina no Estado do Paraná. Arquivo Brasileiro de Medicina Veterinária e Zootecnia, Belo Horizonte, v. 61, p. 66-76, 2009. Suplemento 1.

DIAS, R. A.; BELCHIOR, A. P. C.; FERREIRA, R. S.; GONÇALVES, R. C.; BARÃO. R. S. C.; SOUSA, P. R.; SANTOS, A. M. A.; AMAKU, M.; FERREIRA, F.; TELLES, E. O.; GRISI-FILHO, J. H. H.; HEINEMANN, M. B.; GONÇALVES, V. S. P.; FERREIRA NETO, J. S. Controlling bovine brucellosis in the State of São Paulo, Brazil: results of ten years of vaccination program. Semina: Ciências Agrárias, Londrina, v. 37, n. 5, p. 3505-3518, 2016a. Suplemento 2.

DIAS, R. A.; STANOJLOVIC, F. M. U.; BELCHIOR, A. P. C.; FERREIRA, R. S.; GONÇALVES, R. C.; AGUIAR, R. S. C. B.; SOUSA, P. R.; SANTOS, A. M. A.; AMAKU, M.; FERREIRA, F.; TELLES, E. O.; GRISI-FILHO, J. H. H.; GONÇALVES, V. S. P.; HEINEMANN, M. B.; FERREIRA NETO, J. S. Prevalence and risk factors for bovine tuberculosis in the state of São Paulo, Brazil. Semina: Ciências Agrárias, Londrina, v. 37, n. 5, p. 3673-3684, 2016b. Suplemento 2.
DONAGHY, J. A.; TOTTON, N. L.; ROWE, M. T. Evaluation of culture media for the recovery of Mycobacterium avium subsp. paratuberculosis from cheddar cheese. Letters in Applied Microbiology, London, v. 37, n. 4, p. 285-291, 2003.

DONAGHY, J. A.; TOTTON, N. L.; ROWE, M. T. Persistence of Mycobacterium avium subsp. paratuberculosis during manufacture and ripening of Cheddar cheese. Applied and Environmental Microbiology, Washington, v. 70, n. 8, p. 4899-4905, 2004.

ESTADO DE MINAS GERAIS. Lei Estadual n. 19.492 de 13 de janeiro de 2011 (altera a lei n. 14.185 de 31/01/2002). Dispõe sobre o processo de produção do Queijo Minas artesanal e dá outras providências. Belo Horizonte: DOE 14 de janeiro de 2011, 2011. Disponível em: <https://www.legisweb.com.br/ legislacao/?id=142617>. Acesso em: 05 out. 2016.

ESTADO DE PERNAMBUCO. Lei n. 13.376 de 20 de dezembro de 2007. Dispõe sobre o processo de Produção do queijo artesanal e dá outras providências (Alterações dadas pela Lei $n^{\circ} 14.933$, de 4 de abril de 2013). Recife: DOE 21 de dezembro de 2007. Disponível em: <http:// legis.alepe.pe.gov.br/arquivoTexto. aspx?tiponorma $=1 \&$ numero $=13376 \&$ complemento $=0 \&$ ano $=2007 \&$ tipo $=>$. Acesso em: 05 out. 2016.

FALENSKI, A.; MAYER-SCHOLL, A.; FILTER, M.; GÖLLNER, C.; APPEL, B.; NÖCKLER, K. Survival of Brucella spp. in mineral water, milk and yogurt. International Journal of Food Microbiology, Torino, v. 145, n. 1, p. 326-330, 2011.

FOOD AND DRUG ADMINISTRATION FDA. Brucella species; Mycobacterium bovis. In: LAMPEL, K. A.; AL-KHALDI, S.; KAHILL, S. M. Bad bug book, handbook of foodborne pathogenic microorganisms and natural toxins. $2^{\text {th }}$ ed. Silver Spring: FDA, 2012. Available at: <http://www. fda.gov/Food/ FoodbornelllnessContaminants/ CausesOfIllnessBadBugBook/ucm2006773.htm> Accessed: 15 dec. 2015.

FORGRAVE, R. W.; DONAGHY, J.; ROWE, M. T. Work carried out on M. bovis. In: VOYSEY, P. A. Persistence of Mycobacterium bovis and verotoxin-producing Escherichia coli (VTEC) in UK-made raw-milk cheeses (B12008). Belfast: Final Report. Food Standards Agency, 2014. p. 135-183. Available at: <https://www. food.gov.uk/sites/default/files/822-1-1503_FS231037 Combined_cheese_report.pdf $>$. Accessed at: 26 oct. 2015. 
GALVIS, J. O. A.; GRISI-FILHO, J. H. H; COSTA, D.; SAID, A. L. P. R.; AMAKU, M.; DIAS, R. A.; FERREIRA, F.; GONÇALVES, V. S. P.; HEINEMANN, M. B.; TELLES, E. O.; FERREIRA NETO, J. S. Epidemiologic characterization of bovine tuberculosis in the state of Espírito Santo, Brazil. Semina: Ciências Agrárias, Londrina, v. 37, n. 5, p. 3567-3578, 2016. Suplemento 2.

GILMAN, H. L.; DAHLBERG, A. C.; MARQUARDT, J. C. The occurrence and survival of Brucella abortus in Cheddar and Limburger cheese. Journal of Dairy Science, Champaign, v. 29, n. 2, p. 71-85, 1946.

GUEDES, I. B.; BOTTENE, I. F. N.; MONTEIRO, L. A. R. C.; LEAL FILHO, J. M.; HEINEMANN, M. B.; AMAKU, M.; GRISI-FILHO, J. H. H.; DIAS, R. A.; FERREIRA, F.; TELLES, E. O.; GONÇALVES, V. S. P.; FERREIRA NETO, J. S. Prevalence and risk factors for bovine tuberculosis in the state of Mato Grosso do Sul, Brazil. Semina: Ciências Agrárias, Londrina, v. 37, n. 5, p. 3579-3588, 2016. Suplemento 2.

HARRIS, N. B.; PAYEUR, J.; BRAVO, D.; OSORIO, R.; STUBER, T.; FARRELL, D.; PAULSON, D.; TREVISO, S.; MIKOLON, A.; RODRIGUEZ-LAINZ, A.; CERNEK-HOSKINS, S.; RAST, R.; GINSBERG, M.; KINDE, H. Recovery of Mycobacterium bovis from soft fresh cheese originating in Mexico. Applied and Environmental Microbiology, Washington, v. 73, n. 3, p. 1025-1028, 2007.

INTERNATIONAL COMMISSION FOR THE MICROBIOLOGICAL SPECIFICATIONS OF FOODS - ICMSF. Brucella: capítulo 3. In: Micro-organisms in foods 5: characteristics of microbial pathogens. New York: Kluwer Academic/Plenum Publishers, 1996. 515 p.

INLAMEA, O. F.; ROCHA, A. B.; FERREIRA, F.; GRISI-FILHO, J. H. H.; HEINEMANN, M. B.; DIAS, R. A.; TELLES, E. O.; GONÇALVES, V. S. P.; AMAKU, M.; FERREIRA NETO, J. S. Effect of vaccination in lowering bovine brucellosis in the state of Rondônia, Brazil. Semina: Ciências Agrárias, Londrina, v. 37, n. 5, p. 3493-3506, 2016. Suplemento 2.

JAY, J. M. Modern food microbiology. $6^{\text {th }}$ ed. Gaithersburg: Aspen Publishers, Inc., 2000. 679 p.

KARA, R.; AKKAYA, L. Behavior of Brucella abortus and Brucella melitensis in Afyon Tulum cheese. Journal of Food Safety, Malden, v. 35, n. 1, p. 13-18, 2015.

KLEIN-GUNNEWIEK, M. F. C.; AMAKU, M.; DIAS, R. A.; FERREIRA, F.; GITTI, C. B.; PEREIRA, L. A.; FIGUEIREDO, V. C. F.; LOBO, J. R.; GONÇALVES, V. S. P.; FERREIRA NETO, J. S. Situação epidemiológica da brucelose bovina no Estado do Rio de Janeiro. Arquivo Brasileiro de Medicina Veterinária e Zootecnia, Belo Horizonte, v. 61, p. 77-84, 2009. Suplemento 1.

LAFONT, J.; LAFONT, P. Observations about some modifications of the koch bacillus during ripening of blue cheese. Bulletin de L'Academie Veterinaire de France, Paris, v. 53, n. 4, p. 457-461, 1981.

LEAL-FILHO, J. M.; BOTTENE, I. F. N.; MONTEIRO, L. A. R. C.; PELlEGRIN, A. O.; GONÇALVES, V. S. P.; FERREIRA, F.; DIAS, R. A.; AMAKU, M.; TELLES, E. O.; GRISI-FILHO, J. H. H.; HEINEMANN, M. B.; FERREIRA NETO, J. S. Control of bovine brucellosis from 1998 to 2009 in the state of Mato Grosso do Sul, Brazil. Semina: Ciências Agrárias, Londrina, v. 37, n. 5, p. 3467-3478, 2016. Suplemento 2.

LIMA, P. B.; NASCIMENTO, D. L.; ALMEIDA, E. C.; PONTUAL, K. A. Q.; AMAKU, M.; DIAS, R. A.; FERREIRA, F.; GONÇALVES, V. S. P.; TELLES, E. O.; GRISI-FILHO, J. H. H.; HEINEMANN, M. B.; SILVA, J. C. R.; FERREIRA NETO, J. S. Epidemiological situation of bovine tuberculosis in the state of Pernambuco, Brazil. Semina: Ciências Agrárias, Londrina, v. 37, n. 5, p. 3601-3610, 2016. Suplemento 2.

MACUAMULE, C. L. S.; WIID, I. J.; VAN HELDEN, P. D.; TANNER, M.; WITTHUHN, R. C. Effect of milk fermentation by kefir grains and selected single strains of lactic acid bacteria on the survival of Mycobacterium bovis BCG. International Journal of Food Microbiology, Torino, v. 217, p. 170-176, 2016.

MCFADDEN, J. J.; COLLINS, J.; BAEMAN, B.; ARTHUR, M.; GITNICK, G. Mycobacteria in Crohn's disease: DNA probes identify the Wood Pigeon strain of Mycobacterium avium and Mycobacterium paratuberculosis from human tissue. Journal Clinical Microbiology, Washington, v. 30, n. 2, p. 3070-3073, 1992.

MÉNDEZ-GONZÁLEZ, K. Y.; HERNÁNDEZCASTRO, R.; CARRILLO-CASAS, E. M.; MONROY, J. F.; LÓPEZ-MERINO, A.; SUÁREZ-GÜEMES, F. Brucella melitensis survival during manufacture of ripened goat cheese at two temperatures. Foodborne Pathogens and Disease, New Rochelle, v. 8, n. 12, p. 1257-1261, 2011.

MILKPOINT. IBGE: produção de leite cresceu 2,7\% em 2014; Sul tornou-se a maior região produtora. Leite \& mercado. Giro lácteo. Piracicaba, 2015. Disponível em: $\quad<$ http://www.milkpoint.com.br/cadeia-do-leite/ giro-lacteo/ibge-producao-de-leite-cresceu-27-em-2014sul-tornouse-a-maior-regiao-produtora-97326n.aspx>. Acesso em: 10 dez. 2015. 
NÉSPOLI, J. M. B.; NEGREIROS, R. L.; AMAKU, M.; DIAS, R. A.; FERREIRA, F.; TELLES, E. O.; HEINEMANN, M. B.; GRISI-FILHO, J. H. H.; GONÇALVES, V. S. P.; FERREIRA NETO, J. S. Epidemiological situation of bovine tuberculosis in the state of Mato Grosso, Brazil. Semina: Ciências Agrárias, Londrina, v. 37, n. 5, p. 3589-3600, 2016. Suplemento 2.

OGATA, R. A.; GONÇALVES, V. S. P.; FIGUEIREDO, V. C. F.; LOBO, J. R.; RODRIGUES, A. L.; AMAKU, M.; FERREIRA, F.; FERREIRA NETO, J. S.; DIAS, R. A. Situação epidemiológica da brucelose bovina no Estado do Tocantins. Arquivo Brasileiro de Medicina Veterinária e Zootecnia, Belo Horizonte, v. 61, p. 126134, 2009. Suplemento 1.

OLIVEIRA, L. F.; DORNELES, E. M. S.; MOTA, A. L. A. A.; GONÇALVES, V. S. P.; FERREIRA NETO, J. S.; FERREIRA, F.; DIAS, R. A.; TELLES, E. O.; GRISIFILHO, J. H. H.; HEINEMANN, M. B.; AMAKU, M.; LAGE, A. P. Seroprevalence and risk factors for bovine brucellosis in the State of Minas Gerais, Brazil. Semina: Ciências Agrárias, Londrina, v. 37, n. 5, p. 3449-3446, 2016. Suplemento 2.

PLOMMET, M.; FENSTERBANK, R.; VASSAL, L.; AUCLAIR, J.; MOCQUOT, G.; VACHOT, J. C.; COURAULT, M.; MUSSET, D. Survival of Brucella abortus in ripened soft cheese made from naturally infected cow's milk. Le Lait, Les Ulis, v. 68, n. 3, p. 115120, 1988.

QUEIROZ, M. R.; GROFF, A. C. M.; SILVA, N. S.; GRISI-FILHO, J. H. H.; AMAKU, M.; DIAS, R. A.; TELLES, E. O.; HEINEMANN, M. B.; FERREIRA NETO, J. S.; GONÇALVES, V. S. P.; FERREIRA, F. Epidemiological status of bovine tuberculosis in the state of Rio Grande do Sul, Brazil. Semina: Ciências Agrárias, Londrina, v. 37, n. 5, p. 3647-3658, 2016. Suplemento 2.

RIBEIRO, L. A.; GONÇALVES, V. S. P.; FRANCISCO, P. F. C.; MOTA, A. L. A. A.; NASCIMENTO, G. T.; LICURGO, J. B.; FERREIRA, F.; GRISI-FILHO, J. H. H.; FERREIRA NETO, J. S.; AMAKU, M.; DIAS, R. A.; TELLES, E. O.; HEINEMANN, M. B.; BORGES, J. R. J. Epidemiological status of bovine tuberculosis in the Federal District of Brazil. Semina: Ciências Agrárias, Londrina, v. 37, n. 5, p. 3561-3566, 2016. Suplemento 2.

ROCHA, B. B.; SILVA, M. R.; SOUZA, G. N.; MOREIRA, M. A. S.; FARIA, L. S.; SAMPEDRO, G. D. Prevalência e fatores associados ao consumo de queijo não pasteurizado entre pacientes com tuberculose de uma área urbana do Brasil. Revista Brasileira de Ciência Veterinária, Niterói, v. 21, n. 2, p. 96-100, 2014.
ROCHA, W. V.; GONÇALVES, V. S. P.; COELHO, C. G. N. F. L.; BRITO, W. M. E. D.; DIAS, R. A.; DELPHINO, M. K. V. C.; FERREIRA, F.; AMAKU, M.; FERREIRA NETO, J. S.; FIGUEIREDO, V. C. F.; LOBO, J. R.; BRITO, L. A. B. Situação epidemiológica da brucelose bovina no Estado de Goiás. Arquivo Brasileiro de Medicina Veterinária e Zootecnia, Belo Horizonte, v. 61, p. 27-34, 2009. Suplemento 1.

ROCHA, W. V.; JAYME, V. S.; MOTA, A. L. A. A.; BRITO, W. M. E. D.; PIRES, G. R. C.; GRISI-FILHO, J. H. H.; DIAS, R. A.; AMAKU, M.; TELLES, E. O.; HEINEMANN, M. B.; FERREIRA, F.; FERREIRA NETO, J. S.; GONÇALVES, V. S. P. Prevalence and herd-level risk factors of bovine tuberculosis in the State of Goiás, Brazil. Semina: Ciências Agrárias, Londrina, v. 37, n. 5, p. 3625-3628, 2016. Suplemento 2.

ROWE, M. T.; DONAGHY, J. Mycobacterium bovis: the importance of milk and dairy products as a cause of human tuberculosis in the UK. A review of taxonomy and culture methods, with particular reference to artisanal cheeses. International Journal of Dairy Technology, Huntingdon, v. 61, n. 4, p. 317-326, 2008.

SALÄUN, F.; MIETTONB，B.; GAUCHERON, F. Buffering capacity of dairy products. International Dairy Journal, Edmonton, v. 15, n. 22, p. 95-109, 2005.

SILVA, M. C. P.; GONÇALVES, V. S. P.; MOTA, A. L. A. A.; KOLODA, M.; FERREIRA NETO, J. S.; GRISIFILHO, J. H. H.; DIAS, R. A.; AMAKU, M.; TELLES, E. O.; FERREIRA, F.; HEINEMANN, M. B.; ALFIERI, A. A.; MULLER, E. E. Prevalence and herd-level risk factors for bovine tuberculosis in the state of Paraná, Brazil. Semina: Ciências Agrárias, Londrina, v. 37, n. 5, p. 3611-3624, 2016a. Suplemento 2.

SILVA, N. S.; GROFF, A. C. M.; VIDOR, A. C. M.; GRISI-FILHO, J. H. H.; HEINEMANN, M. B.; DIAS, R. A.; TELLES, E. O.; GONÇALVES, V. S. P.; AMAKU, M.; FERREIRA, F.; FERREIRA NETO, J. S. Epidemiological situation of bovine brucellosis after implementation of a vaccination program in Rio Grande do Sul state, Brazil. Semina: Ciências Agrárias, Londrina, v. 37, n. 5, p. 3507-3518, 2016. Suplemento 2.

SILVA, V.G. S. O.; DIAS, R.A.; FERREIRA, F.;AMAKU, M.; COSTA, E. L. S.; LOBO, J. R.; FIGUEIREDO, V. C. F.; GONÇALVES, V. S. P.; FERREIRA NETO, J. S. Situação epidemiológica da brucelose bovina no Estado de Sergipe. Arquivo Brasileiro de Medicina Veterinária e Zootecnia, Belo Horizonte, v. 61, p. 109-117, 2009. Suplemento 1. 
SINHA, R. N. Mycobacterium bovis (Chapter 11). In: International Dairy Federation, IDF/FIL. The significance of pathogenic microorganisms in raw milk. Bruxels: International Dairy Federation, IDF/FIL, 1994. p. 141-166.

SOBESTIANSKY, J.; WENTZ, I.; SILVEIRA, P. R. S.; SESTI, L. C. A.; BARCELLOS, D. E. S. N.; LOPEZ, A. C. Limpeza e desinfecção. In: Embrapa Suínos e Aves. Suinocultura intensiva. Produção, manejo e saúde do rebanho. Concórdia: EMBRAPA, 1998. p. 113-134.

SOUSA, D. D. P.; PEREIRA, E. D.; GERMANO, M. I. S.; DIAS, R. A.; GUIMARÃES, R.; PINHEIRO, S. R.; BALIAN, S. C.; TELLES, E. O. Fatores relacionados ao consumo de produtos lácteos informais no Município de Jacareí - SP. Higiene Alimentar, São Paulo, v.23, n. 178/179, p. 119-126, 2009.

SPAHR, U.; SCHAFROTH, K. Fate of Mycobacterium avium subsp. paratuberculosis in swiss hard and semihard cheese manufactured from raw milk. Applied and Environmental Microbiology, Washington, v. 67, n. 9, p. 4199-4205, 2001.
SUNG, N.; COLLINS, M. T. Effect of three factors in cheese production ( $\mathrm{pH}$, salt and heat) on Mycobacterium subsp. paratuberculosis Viability. Applied Environmental Microbiology, Washington, v. 66, n. 4, p. 1334-1339, 2000.

VELOSO, F. P.; BAUMGARTEN, K. D.; MOTA, A. L. A. A.; FERREIRA, F.; FERREIRA NETO, J. S.; GRISI-FILHO, J. H. H.; DIAS, R. A.; AMAKU, M.; TELLES, E. O.; HEINEMANN, M. B.; GONÇALVES, V. S. P. Prevalence and herd-level risk factors of bovine tuberculosis in the State of Santa Catarina, Brazil. Semina: Ciências Agrárias, Londrina, v. 37, n. 5, p. 3659-3672, 2016. Suplemento 2.

VENDRAME, F. B.; AMAKU, M.; FERREIRA, F.; TELLES, E. O.; GRISI-FILHO, J. H. H.; GONÇALVES, V. S. P.; HEINEMANN, M. B.; FERREIRA NETO, J. S.; DIAS, R. A. Epidemiologic characterization of bovine tuberculosis in the State of Rondônia, Brazil. Semina: Ciências Agrárias, Londrina, v. 37, n. 5, p. 3639-3646, 2016. Suplemento 2 . 
